\title{
PROGRAM PENDIDIKAN KECAKAPAN LITERASI KOMPUTER MELALUI MAGANG TRADISIONAL MASA PENDEMI COVID-19
}

\author{
Mustakim Mustakim, Hamim Farhan², Ode Mohamad Man Arfa Ladamay ${ }^{3}$, \\ Risky Mila Sary ${ }^{4}$, Utami Nurlali $^{5}$ \\ ${ }^{1,4,5}$ Program Studi Pendidikan Islam Anak Usia Dini Universitas Muhammadiyah Gresik \\ ${ }^{2,3}$ Program Studi Pendidikan Agama Islam Universitas Muhammadiyah Gresik \\ 1'mustakim@umg.ac.id , ${ }^{2}$ hamim@umg.ac.id, ${ }^{3}$ ode_arfa@umg.ac.id, ${ }^{4}$ riskymila@gmail.com, \\ nurlailiutami8@gmail.com
}

Received: Juli, 2020; Accepted: September, 2020

\begin{abstract}
Digital literacy in the face of a new normality for the people's choice menjali daily activities. Computer literacy skills education pandemic period covid-19 learners equality peket $\mathrm{C}$ is a new experience trainee (student). This study aims to describe the management of computer literacy skills education program and an overview of the traditional fingering patterns of computer literacy skills education pandemic period covid-19. The research method used is a qualitative method with an ethnographic approach. This research analyzes using the method of data collection, simplification of data, and presentation of data, as well as conclusions and verification. This study Response 20 apprentices equality Package C in SKB Cerme Gresik. The research result shows that as the use of digital technology, the mastery of computers and networks, as well as information. The results of this study illustrate that the management of future pandemic computer literacy program covid-19 in general by using an online home.
\end{abstract}

Keywords: Education, Computer Literacy, Digital Literacy, traditional apprenticeship, pandemic covid-19

\begin{abstract}
Abstrak
Literasi digital dalam menghadapi kenormalan baru menjadi pilihan masyarakat untuk menjali aktifitas sehari-hari. Pendidikan kecakapan literasi komputer masa pendemi covid-19 peserta didik kesetaraan peket $\mathrm{C}$ merupakan pengalaman baru pemagang (peserta didik). Penelitian ini bertujuan untuk menggambarkan pengelolaan program pendididkan kecakapan literasi komputer dan gambaran pola megang tradisional pendidikan kecakapan literasi komputer masa pendemi covid-19. Metode penelitian yang digunakan dengan metode kualitatif dengan pendekatan etnografis. Analisis penelitian ini menggunakan cara koleksi data, penyederhanaan data, dan penyajian data, serta pengambilan kesimpulan dan verivikasi. Response penelitian ini 20 peserta magang kesetaraan Paket C di SKB Cerme Gresik. Hasil penelitian menggambarkan bahwa sebagai pemanfaatan teknologi digital, penguasaan perangkat komputer dan jaringan, serta informasi. Hasil penelitian ini menggambarkan bahwa pengelolaan program literasi komputer masa pendemi covid-19 secara umum dengan menggunakan daring dirumah.
\end{abstract}

Kata Kunci: Pendidikan, Literasi Komputer, Literasi digital, magang tradisional, pendemi covid-19.

How to Cite: Mustakim, Farhan, Ladamay, Sary, Nurlali. (2020). Program Pendidikan Kecakapan Literasi Komputer Melalui Magang Tradisional Masa Pendemi Covid-19. CommEdu (Community Education Journal) 3 (3), 278-289. 


\section{PENDAHULUAN}

Pada era disrupsi masyarakat tidak hanya di tuntut memiliki Izajah saja, akan tetapi juga harus memiliki kecakapan atau keterampilan yang menunjang dalam keilmuan. Mulai dari kecakapan sosial (sosial skills), kecakapan personal (personal skills), kecakapan vokasional (vocational skills), dan kecakapan akademik (academik skills). Dari keempat kecakapan hidup ini, menjadi bekal masyarakat dalam menjalani keseharian di lingkungan masyarakat. Era disrupsi merupakan era dimana masyarakat ditawarkan pada kondisi yang lebih mudah, sederhana, menarik, dan meyenangkan. Kondisi dimana aktifitas dunia nyata sudah beralih pada dunia maya. Era disrupsi membawa manusia kearah dunia yang digitalisasi (Eti, 2019).

Kecepatan inovasi teknologi membuat masyarakat mulai mengupgrade kecakapan yang dimiliki. Abad 21 merupakan abad yang paling kritis dimana kecanggihan teknologi melebihi kemampuan penggunanya (Muliawaty 2019). Berbagai inovasi bermunculan di masyarakat yang memudahkan dalam proses pekerjaan manusia. Dampak pendemi Covid-19 juga memberikan ruang masyarakat untuk menggunakan teknologi secara kontinyu di rumah.

Aktifitas work from home (WFH) selama pendemi Covid-19 juga memberikan kesempatan masyakat untuk menggunakan teknologi secara maksimal dalam mendukung pekerjaan masyarakat. Pembatasan Sosial Berskala Besar (PSBB) juga merubah tatan kehidupan masyarakat yang harus learning at home, dan stay at home. Hal ini sebagai upaya meminimalisir penyebaran virus corona dengan melakukan lockdown pada suatu wilayah yang berdampak wabah virus corona (Rezki, 2020).

Kecakapan literasi komputer bagi masyarakat Kota merupakan hal biasa. Namun berbeda dengan masyarakat diwilayah pedesaan yang jauh dari akses teknologi. Terlebih dampak covid-19 membuat peserta didik Paket $\mathrm{C}$ harus melakukan kegiatan pembelajaran secara daring.

Pendidikan kecakapan literasi merupakan nilai penting untuk meningkatkan keterampilan peserta didik. Dalam World Economic Forum enam literasi dasar yang menjadi nilai penting untuk masyarakat, diantaranya: (1) pengusaan literasi baca tulis, (2) penguasaan literasi numerasi, (3) penguasaan literasi sains, (4) penguasaan literasi digital, (5) penguasaan literasi finansial, dan (6) penguasaan literasi budaya dan kewargaan (Rokhman, 2019).

Literasi Digital menjadi kebutuhan mendesak selama pendemi Covid-19, seiring dengan kemanjuan informasi dan teknologi terbarukan dan tanpa diimbangi dengan kecerdasan pengguna teknologi. Adapun pentingnya literasi digital untuk di jadikan pembelajaran pengembangan pendidikan di era cyber sebagai berikut: (1) kemampuan berpikir kritis, inovatif, dan kreatif, (2) pemecahan masalah yang terjadi, (3) Kemampuan mengetahui arti dari pemanfaatan teknologi modern, (4) tidak menggunakan teknologi untuk wadah melakukan kejahatan, dan (5) sealalu menjadi pengguna yang baik (Budi Sudradjat 2019). Penggunaan teknologi yang tidak terkendali dan diluar batas kewajaran mengakibatkan timbulnya nilai positif dan negatif dengan pengembangan literasi digital (Pers 2017). Dua sisi positif dan negatif, seiring dengan perkembangan peralatan digital, serta menjadi tantangan dan sekaligus peluang.

Konsep literasi digital sebagai kemampuan memahami dan menggunakan informasi dalam banyak format dari berbagai sumber ketika itu disajikan secara digital melalui komputer. Literasi digital diartikan sebagai sebuah kemampuan untuk menggunakan teknologi digital 
280 Mustakim, Farhan, Ladamay, Sary, Nurlali, Program Pendidikan Kecakapan Literasi Komputer Melalui Magang Tradisional Masa Pendemi Covid-19

dan tahu kapan dan bagaimana menggunakannya. Literasi digital adalah kemampuan menggunakan teknologi digital, perangkat atau jaringan komunikasi, evaluasi, membuat dan menggunakan informasi (Munir, 2017).

Kemampuan memahami dan menggunakan teknologi informasi dalam berbagai format dari berbagai sumber ketika disajikan melalui komputer. Literasi digital ini meliputi kemampuan membaca dan mengintrepretasi media, memproduksi data dan gambar melalui manipulasi digital dan mengevaluasi serta menerapkan pertambahan pengetahuan baru dari lingkungan digital (Munir, 2017).

Literasi TIK (teknologi informasi dan komunikasi) dijelaskan dengan dua sudut pandang (Tim GLN Kemendikbud 2017). Pertama, Literasi Teknologi (Technological Literacy) sebelumnya dikenal dengan sebutan Computer Literacy merujuk pada pemahaman tentang teknologi digital termasuk di dalamnya pengguna dan kemampuan teknis. Kedua, menggunakan Literasi Informasi (Information Literacy). Literasi ini memfokuskan pada satu aspek pengetahuan, seperti kemampuan untuk memetakan, mengidentifikasi, mengolah, dan menggunakan informasi digital secara optimal. Pada negara maju, magang digunakan sebagai proses belajar dan bekerja, di Amerika Serikat magang digunakan sebagai cara untuk naik pangkat serta menduduki jabatan baru di perusahaan swasta, organisasi, dan direktur TV, serta lain-lain. The Apprentice as a weekly ritual, with employees required to watch the show on Thursday evenings, followed with official Friday morning discussions of the previous evening's episode's “lessons" (Lair, 2007).

Proses belajar melalui magang terjadi dalam bentuk belajar sambil bekerja, pemagang (peserta didik) akan membiasan diri untuk mengikuti proses pekerjaan yang sudah biasa dilakukan oleh sumber belajar (tutor). Kegiatan belajar melalui magang merupakan bagian dari kegiatan belajar umat manusia, yang keberadaannya jauh sebelum pendidikan persekolahan lahir dalam kehidupan manusia. Berawal dari lingkungan keluarga akibat terjadinya interaksi antara orang tua atau anak, melalui pola transmisi pengetahuan, keterampilan dan nilai yang dilakuakan oleh orang tua terhadap anaknya dalam bentuk asuhan, suruhan, larangan, dan bimbingan (Sudjana, 2004).

Pemahaman literasi digital yang buruk akan berpengaruh pada psikologis anak dan remaja yang cenderung menghina orang lain, menimbulkan sikap iri terhadap orang lain, mengakibatkan depresi, terbawa arus suasana hati terhadap komentar negatif, serta terbiasa berbicara dengan bahasa kurang sopan (Pratiwi and Pritanova, 2017).

Meminimalisir dampak literasi digital selama masa pendemi covid-19 maka di butuhkan keterampilan untuk peserta didik kesetaraan paket C. Penelitian ini bertujuan untuk menggali pengelolaan program pendidikan kecakapan literasi komputer masa pendemi covid-19 pada peserta didik Kesetaraan Paket C di SKB Cerme Gresik, dan untuk menggambarkan pola magang tradisional pendidikan kecakapan literasi komputer masa pendemi covid-19 peserta didik Kesetaraan Paket C di SKB Cerme Gresik.

\section{METODE}

Penelitian program pendidikan kecakapan literasi komputer melalui magang tradisional masa pendimi covid-19 dilaksanakan pada bulan Januari sampai April 2020, peneliti menggunakan metode diskriptif kualitatif, dan pendekatan etnografis. Pendekatan etnografis adalah prosedur kualitatif yang mendeskripsikan, menganalisis dan menginterpretasikan pola-pola 
yang sama dalam prilaku, keyakinan dan bahasa suatu kelompok budaya, yang berkembang seiring waktu (Creswell 2015). Penelitian ini berlokasi pada Sanggar Kegiatan Belajar (SKB), Jl. Jurit No. 02, Cerme Kidul Kecamatan Cerme Kabupaten Gresik Provinsi Jawa Timur. Dengan subjek penelitian 20 peserta didik progam kesetaraan paket C setara SMA.

Teknik pengumpulan data penelitian dengan menggunakan teknik wawancara, observasi dan dokumentasi secara daring dan luring, tatap muka sebelum pendemi Covid-19. Data penelitian program pendidikan kecakapan literasi komputer melalui magang tradisional masa pendemi covid-19 yang dikumpulkan di sederhanakan kemudian disajikan secara sistimatis sehingga mendapatkan kesimpulan yang akurat dan kridibel. Sehingga untuk menguji tingkat keakuratan dan credibility penelitian ini peneliti menggunakan triangulasi sumber, metode dan waktu pada subyek penelitian.

Analisis data penelitian yang dikumpulkan baik daring, luring dan offline, dalam penelitian kualitatif analisis data difokuskan selama proses kegiatan sebelum pendemi covid-19 dilapangan, bersamaan dengan pengumpulan data daring selama kegiatan dirumah masingmasing peserta didik dan setelah selesai kegiatan pendidikan kecakapan literasi komputer dalam periode tertentu. Melalui analisis data dengan cara koleksi data, penyederhanaan data, dan penyajian data, serta pengambilan kesimpulan dan verivikasi.

\section{HASIL DAN PEMBAHASAN}

\section{Hasil}

Pengelolaan Program Pendidikan Kecakapan Literasi Komputer Masa Pendemi Covid-19 Pada Peserta didik Kesetaraan Paket C

Program pendidikan kecakapan literasi komputer di era saat ini merupakan kebutuhan yang harus dipenuhi dan dikuasai oleh peserta didik. Penguasaan literasi komputer sudah menjadi dasar keterampilan peserta didik dalam memasuki dunia kerja.

Keterampilan literasi komputer merupakan kebutuhan yang krusial pada era digital saat ini. Pengelolaan program pendidikan kecakapan literasi komputer di Sanggar Kegiatan Belajar Cerme Gresik memiliki tujuan meliputi: peserta didik memiliki keterampilan komputer dalam memasuki dunia kerja, memiliki pengetahuan komputer, memiliki sikap yang baik dalam memasuki dunia kerja, motivasi yang tinggi, etos kerja yang baik, memiliki kesadaran akan pentingnya pendidikan, memiliki kesempatan yang sama dalam pendidikan, dapat menggunakan teknologi digital, menguasai perangkat dan jaringan komunikasi, pandai menggunakan informasi, dapat memilah berita yang hoax, dapat memproduksi data dan memiliki kemampuan mengevaluasi.

Program keterampilan literasi komputer masa pendemi covid-19 yang dilaksanakan oleh Sanggar Kegiatan Belajar Cerme Gresik secara umum ingin memberikan bekal peserta didik tentang kecakapan penggunaan teknologi digital, penggunaan informasi, jaringan dan perangkat komputer sesuai dengan era saat ini.

Adapun parameter capaian pembelajaran program literasi komputer yang sesuai dengan Kerangka Kualifikasi Nasional Indonesia (KKNI) Teknisi Komputer jenjang III (Kualifikasi, Indonesia, and Framework 2014). Standar kompotensi lulusan (SKL) program pendidikan kecakapan literasi komputer mengacu pada SKL antara lain: 1) sikap dan tata nilai, 2) kemampuan dibidang kerja, 3) pengetahuan yang dikuasi, dan 4) hak dan tanggung jawab pada bidang kerja (Pembinaan et al. 2014). 
Kompetensi lulusan teknik komputer jaringan pada peserta didik paket C di SKB Cerme Gresik masa pendemi covid-19 mengacu pada SKL, sikap dan tata nilai yakni mengaktualisasi karakter dan kepribadian, meliputi a) bertakwa kepada Tuhan Yang Maha Esa, b) memiliki moral, etika dan kepribadian yang baik di dalam menyelesaikan tugasnya, c) berperan mewujudkan etika dan kepribadian yang baik sebagai warga Negara yang bangga dan cinta tanah air serta mendukung perdamaian dunia, d) bekerja sama dan memiliki kepekaan sosial dan kepedulian yang tinggi terhadap masyarakat dan lingkungan, e) menghargai keanekaragaman budaya, pandangan, kepercayaan, dan agama, f) menjunjung tinggi penegakan hukum serta semangat mendahulukan kepentingan bangsa serta masyarakat.

Kemampuan dibidang Kerja yakni mampu merakit dan merawat kinerja komputer serta memperbaiki kerusakan perangkat keras (modul level) dan lunak pada komputer, dengan aman dan sesuai dengan standar mutu, meliputi: a) menerjemahkan kebutuhan klien atau perangkat keras dan lunak komputer, perawatan, dan perbaikan sesuai dengan kebutuhan, b) merancang dan merakit perangkat keras (Modul level) dan lunak komputer sesuai kebutuhan, spesifikasi yang optimal, c) melalukan perawatan perangkat lunak, d) melakukan pemeliharaan data dengan membuat data beck-up, menjalankan anti virus, dan melakukan data recovery, e) mendiagnosa dan memperbaiki kinerja komputer baik dari perangkat keras dan perangkat lunak, f) menguju kineja komputer hasil rakitan, perawatan, perbaikan dan tindaklanjut hasil ujicoba, g) menyusun rancangan, anggaran biaya sesuai dengan kebutuhan spesifikasi pengguna, h) mempresentasikan hasil perakitan, perawatan, perbaikan, kepada klien, i) mengevaluasi hasil kinerja secara mandiri.

Pengetahuan yang dikuasi, yakni menguasai pengetahuan, prosedural, faktual, dan teknik komputer, meliputi: a) menguasi konsep umum tentang organisasi proses kerja perangkat keras dan lunak komputer, b) menguasai pengetahuan factual tentang jenis, karakteristik, dan fungsi komponen komputer, c) menguasai pengetahuan oprasional tentang proses perakitan, perawatan, dan perbaikan perangkat keras (modul level), d) memahami prinsip penggunaan alat uji kerja komputer, f) pengetahuan factual tentang gejala kerusakan perangkat kerasa dan lunak komputer, g) prinsip proses perawatan dan perbaikan komputer dan teknik penggunaan alat yang relevan, h) pengetahuan factual tentang perlingdungan hak kekayaan intelektual perangkat lunak komputer, i) prinsip dan teknik berkomunikasi lisan dan tulisan serta menguasai arti dari berbagai istilah perangkat lunak dan keras komputer, j) konsep umum K3 berkaitan dengan pekerjaan merakit, merawat, dan memperbaiki kinerja komputer, dan $\mathrm{k}$ ) teknik penelusuran harga terkini perangkat keras dan lunak dalam Rupiah dan US Dollar.

Hak dan Tanggung Jawab, yakni bertanggung jawab perakitan, perawatan, dan perbaikan kinerja komputer, meliputi: a) bertanggung jawab dalam perakitan, perawatan, dan perbaikan kinerja komputer sesuai dengan standar mutu, dengan memperhatikan $\mathrm{K} 3$, b) bertanggung jawab untuk membimbing rekan kerja yang baru masuk, peserta magang, dan dapat menggantikan pekerjaan orang lain dengan lungkup, kuantitas dan mutu hasil kerja yang sama, c) melakukan komunikasi yang baik dan efektif dengan rekan kerja dan pengguna jasa.

Pengelolaan program pendidikan kecakapan literasi komputer masa pendemi covid-19, dilaksanakan secara daring dirumah masing-masing peserta didik. Dengan dipandu oleh 1 tutor komputer. Dalam pengelolaan program ini dilaksanakan secara daring selama 3 bulan. Beberapa kendala yang dialami oleh peserta didik mulai dari perangkat keras komputer yang ada di SKB, perangkat lunak yang harus di instal pada perangkat komputer/ laptop masingmasing peserta didik. Sedangkan untuk kegiatan online terkendala dengan jaringan internet, sinyal yang susah, dan keterbatasan kuota internet. 
Gambaran Pola Magang Tradisional Pendidikan Kecakapan Literasi Komputer Masa Pendemi Covid-19 Peserta Didik Kesetaraan Paket C

Pada gambaran pola magang tradisional pendidikan kecakapan literasi komputer masa pendemi covid-19, peserta didik mempelajari kecakapan literasi komputer dari berbagai lapisan masyarakat dan keluarga yang terdekat. Dampak pendemi covid-19 membuat peserta didik tidak dapat melaksanakan magang di lembaga mitra yang sudah bekerja sama dengan SKB Cerme Gresik. Peserta didik kesetaraan paket C selama masa pendemi covid-19 tetap bisa melaksanakan magang dengan belajar di rumah menggunakan peralatan komputer yang dimiliki, dan dipandu oleh tutor melalui group WhatsApp. Secara umum pola magang tradisional program pendidikan kecakapan literasi komputer dilaksanakan melalu beberapa tahapan antara lain: 1) tahap identifikasi kebutuhan keterampilan peserta didik (pemagang), 2) tahap pelaksanaan magang, c) tahap penilaian magang, dan d) tahap tindaklanjut magang.

Pada pelaksanaan magang tradisional program pendidikan kecakakapan literasi komputer masa pendemi covid-19 di SKB Cerme Gresik dilaksanakan dengan beberapa tahap meliputi: tahap identifikasi kebutuhan keterampilan peserta didik, pada tahap ini tutor memberikan pemahaman bahwa keterampilan yang dipelajari peserta didik (pemagang) secara keseluruhan adalah teknik komputer jaringan. Dengan pemahaman dan tujuan yang sama maka tahap identifikasi keterampilan yang dipelajari fokus pada satu aspek yakni literasi komputer, serta sumber belajar atau tutor SKB Cerme Gresik merupakan orang yang ahli dan sesuai dengan keilmuan dibidang komputer. Pada tahap ini juga pengorganisasian pemagang dengan memberikan penjelasan pelakasanaan pendidikan kecakapan literasi komputer dilaksanakan secara daring dan mandiri di rumah masing-masing.

Tahap pelaksanaan magang, pada tahap ini pemagang seharusnya melaksanakan pembelajaran di SKB dan praktik di lokasi magang, namun harus melakukan kegiatan pembelajaran secara daring dan mandiri dirumah. Tujuan kegiatan magang ini adalah untuk memberikan pengatahuan, keterampilan, dan sikap dalam menggunakan komputer sebagai kemajuan teknologi.

Pada struktur magang program pendidikan kecakapan literasi komputer melalui magang tradisional masa pendemi covid-19. Struktur magang ini terdiri dari 4 kajian meliputi: a) struktur materi magang, b) klasifikasi (teori dan praktik) magang, c) kontrak pembelajaran magang, dan d) jumlah jam pembelajaran (JP) magang. Pada struktur magang selama masa pendemo covid-19, materi magang disesuaikan dengan SKL dari direktorat kursus dan pelatihan dan dilaksanakan secara daring, meliputi 1) help-desk technicians, 2) computer support specialist, dan 3) technical support specialist. Klasifikasi kegiatan pembelajaran teori pendidikan kecakapan literasi komputer $20 \%$ dan pembelajaran praktik $80 \%$. Dan kontrak pembelajaran magang selama 3 bulan, mulai bulan Februari-April 2020, dengan pembelajaran daring dan mandiri dirumah. Sedangkan untuk jumlah jam pelajaran dilaksanakan satu minggu selama 2 kali yakni hari selasa dan kamis, mulai pukul 09.30-11.00 WIB.

Bahan ajar magang yang diberikana untuk pemagang adalah bahan ajar yang sesuai dengan KKNI meliputi sikap dan tata nilai, kemampuan dibidang kerja, pengetahuan yang dikuasi, dan tanggung jawab pada bidang kealian literasi komputer.

Peserta didik atau pemagang dalam kegiatan ini adalah peserta didik kesetaraan peket $\mathrm{C}$ di SKB Cerme Gresik. Fasilitator atau tutor adalah guru yang mengajarkan materi ajar komputer. Media pembelajaran magang berupa perangkat keras dan lunak komputer. Untuk perangkat keras dan lunak Sanggar Kegiatan Belajar (SKB) sudah menyiapkan di leb Komputer. Sedangkan sarana dan prasaran yang mendukung dalam proses praktik literasi 
komputer sudah disediakan oleh lembaga. Karena dampak pendemi covid-19 maka kegiatan pembelajaran literasi komputer dilaksanakan dirumah masing-masing pemagang, dan pemagang belajar komputer dibimbing oleh orang tua, kerabat, saudara, dan orang terdekat yang memiliki kemampuan menggunakan komputer.

Tahap penilaian magang, pada tahap ini pendidikan kecakapan literasi komputer masa pendemi covid-19 hasil magang dilihat dari kemampuan pemagang sesuai dengan capaian pembelajaran teknisi komputer yang ada di SKL. Untuk evaluasi magang, karena magang tradisional ini dilaksanakan secara daring, dan dirumah melalui belajar mandiri, baik belajar dari orang tua, saudara, kerabat, dan saudara terdekat. Evaluasi ini sebagai tindak lanjut program magang selanjutnya.

Tahap Tindak lanjut Magang, pemagang walaupun melaksanakan magang secara daring dirumah untuk tindak lanjut magang dikaji dari dua aspek meliputi: 1) peningkatan sumber daya manusia (SDM), dan 2) penerapan SDM. Pada peningkatan SDM terlihat dari kemampuan pemagang dalam menguasi keterampilan literasi komputer meliputu: 1) helpdesk technicians, 2) computer support specialist, dan 3) technical support specialist. Sedangkan penerapan SDM, hasil dari kegiatan magang dapat diimplementasikan dalam kegiatan keseharian pemagang, baik dalam mengerjakan tugas sekolah dan persiapan UTBK (Ujian Tulis Berbasis Komputer).

\section{Pembahasan}

Pengelolaan Program Pendidikan Kecakapan Literasi Komputer Masa Pendemi Covid-19 Pada Peserta Didik Kesetaraan Paket C

Masa pendemi covid-19 saat ini menuntut masyarakat untuk beradaptasi dengan semua aspek perubahan, mulai dari aktifitas off line menuju aktifitas online. Pekerjaan sudah beralih dari rumah atau work from home, learning at home, dan stay at home. Magang tradisonal merupakan kegiatan belajar bekerja dari orang terdekat, baik orang tua, kerabat, saudara, dan tetangga. Pada program pendidikan kecakapan literasi komputer melalui kegiatan magang tradisional merupakan alternative pembelajaran selama masa pendemi covid-19. Peserta didik atau pemagang melakukan praktik pembelajaran literasi komputer dari rumah secara daring, dan dibantu oleh orang terdekat secara luring atau offline.

Program keterampilan literasi komputer masa pendemi covid-19 di SKB Cerme Gresik dalam pengelolaannya tetap berpedoman pada indikator standar kompetensi lulusan (SKL) Teknisi Komputer Jaringan III yang berbasis Kerangka Kualifikasi Nasional Indonesia (KKNI) (Kualifikasi et al. 2014). Pengelolaan program ini dilaksanakan secara daring dan luring dengan mengacu pada empat indikator antara lain: sikap dan tata nilai, kemampuan dibidang kerja, pengetahuan yang dikuasai, serta hak dan tanggung jawab pada bidang kerja.

Sikap dan tata nilai, pada indikator ini pemagang dalam hal ini adalah peserta didik kesetaraan Paket C SKB Cerme Gresik, yakni memiliki kemampuan melakukan aktivitas perakitan, perawatan dan perbaikan dengan bersikap sopan, santun, disiplin, menghormati, menghargai kerjasama, buah pikir teman sebagai makhluk ciptaan Tuhan Yang Maha Esa. Melakukan aktivitas tepat waktu, aturan dan terukur, serta saling menerima dan menghargai kritik, saran dan pendapat dari orang lain. Sikap dan tata nilai ini “...merupakan nilai-nilai luhur universal, seperti cinta tuhan, jujur, amanah, kemandirian, hormat, santun, suka tolong menolong, percaya diri, rendah hati, toleransi, dan cinta damai (Dindin 2013). 
Kemampuan di bidang kerja, pemagang memiliki kemampuan dalam mengisi formulir tugas, menyusun daftar pilihan, dan mendapatkan persetujuan tindakakan perakitan, perawatan, dan perbaikan yang sesuai dengan kebutuhan pengguna komputer. Pada tahap perakitan pemagang mengidentifikasi, memiilih, dan memasang komponen spesifikasi komputer sesuai dengan kebutuhan pengguna.

Program keterampilan literasi komputer melalui magang tradisional di SKB Gresik merupakan program pendidikan pada level dasar dengan pemagang mengetahui secara keseluruhan perangkat keras dan perangkat lunak. Pada perangkat lunak terkait dengan pengolahan kata (word processing), pengolahan angka (exel processing) dan pengolahan presentasi (power point processing). Untuk perangkat keras pemagang merakit masingmasing komponen komputer sesuai dengan standar kebutuhan komputer dunia kerja. Sehingga kemampuan di bidang kerja pemagang dapat meningkat sesuai dengan kebutuhan dunia usaha dan dunia industri. Melalui kemampuan "...keterampilan komputer standar yang diperlukan oleh dunia usaha pada umumnya" (Ariz 2012), pemagang dapat bersaing di dunia kerja.

Pemagang juga memiliki kemampuan dalam merawat, memelihara, recovery, dan mengujicoba keseluruhan komponen komputer serta membuat anggaran sesuai dengan kebutuhan pengguna komputer. Pengetahuan yang dikuasai, pemagang dapat menjelaskan organisasi dan proses kerja dari perangkat kerasa dan perangkat lunak, karakteristik, fungsi komponen-komponen komputer, menyebutkan prosedur perakitan, perawatan, dan perbaikan, dapat menggunakan alat uji kinerja komputer, menjelaskan kerusakan komputer, mampu menjelaskan prosedur alat yang relevan untuk perbaikan komputer, mampu menjelaskan perlindungan HKI bagi perangkat lunak komputer yang gratis, legal dan berbayar serta illegal kepada pengguna, dapat menjelaskan secara lisat dan tulisan tentang perangkat komputer, menjelaskan prilaku umum dan etika dalam merakit, ,merawat, dan memperbaiki komputer sesuai dengan keselamatan dan keseharan kerja (K3), serta menjelaskan harga perangkat keras dan lunak sesuai dengan kurs jual IDR dan US Dollar.

Hak dan Tanggung Jawab, pendidikan kecakapan literasi komputer yang di kuasai oleh pemagang merupakan etika yang harus di patuhi oleh pemagang. Dengan adanya hak dan tanggung jawab maka prosedur dalam perakitan, perawatan dan perbaikan komputer sesuai dengan K3. Dalam pendidikan kecakapan literasi komputer dimasa pendemi covid-19 pemagang juga dibimbing secara daring oleh tutur dan rekan sejawat dalam perakitan, perawatan, dan perbaikan komputer. Dan memberikan pelayanan sesuai dengan permintaan klien, serta memiliki kemampuan dalam berkomunikasi yang baik dan benar dengan klien.

\section{Gambaran Pola Magang Tradisional Pendidikan Kecakapan Literasi Komputer Masa Pendemi Covid-19 Peserta Didik Kesetaraan Paket C}

Pola magang tradisional pendidikan kecakapan literasi komputer masa pendemi covid-19 merupakan magang yang dilaksanakan secara daring dan luring dengan kegiatan magang dirumah melalui kegiatan pendidikan informal. Proses belajar melalui magang terjadi dalam bentuk belajar sambil bekerja, pemagang (peserta didik) akan membiasan diri untuk mengikuti proses pekerjaan yang sudah biasa dilakukan oleh sumber belajar (tutor).

Kegiatan belajar melalui magang merupakan bagian dari kegiatan belajar umat manusia, yang keberadaannya jauh sebelum pendidikan persekolahan lahir dalam kehidupan manusia. Berawal dari lingkungan keluarga akibat terjadinya interaksi antara orang tua atau anak, 
melalui pola transmisi pengetahuan, keterampilan dan nilai yang dilakuakan oleh orang tua terhadap anaknya dalam bentuk asuhan, suruhan, larangan, dan bimbingan (Sudjana, 2004).

Gambaran pola magang masa pendemi covid-19 pada pemagang kesetaraan peket C SKB Cerme Gresik yang seharusnya magang ditempat mitra namun harus magang secara mandiri di rumah. Dengan menerapkan social distancing dan Physical distancing sebagai prilaku baru dalam sehari-hari (Sandro, 2011).

Secara umum pada kegiatan magang tradisional masa pendemi covid-19 gambaran program pendidikan literasi komputer dilaksanakan melalu empat tahap meliputi: 1) tahap identifikasi kebutuhan keterampilan peserta didik (pemagang), 2) tahap pelaksanaan magang, c) tahap penilaian magang, dan d) tahap tindaklanjut magang. Pada tahap pertama identifikasi kebutuhan peserta magang, secara keseluruhan peserta didik dalam hal ini pemagang difokuskan pada kegiatan pendidikan literasi komputer. Tujuan kegiatan ini untuk memberikan pemahaman dan keterampilan merakit, merawat, dan memperbaiki komponenkomponen komputer yang sesuai dengan kebutuhan klien dan perkembangan zaman di era digital. Perkembangan dunia digital dapat menimbulkan dua sisi yang berlawanan dalam kaitannya dengan pengembangan literasi digital (Tim GLN Kemendikbud 2017). Sisi positif dan negatif, seiring dengan perkembangan peralatan digital, serta menjadi tantangan dan sekaligus peluang.

Konsep literasi digital sebagai kemampuan memahami dan menggunakan informasi dalam banyak format dari berbagai sumber ketika itu disajikan secara digital melalui komputer. Literasi digital diartikan sebagai sebuah kemampuan untuk menggunakan teknologi digital dan tahu kapan dan bagaimana menggunakannya. Literasi digital adalah kemampuan menggunakan teknologi digital, perangkat atau jaringan komunikasi, evaluasi, membuat dan menggunakan informasi (Munir 2017).

Pada tahap ke dua pelaksanaan magang, pada tahap ini merupakan tahap inti yang memberikan proses pembelajaran dan praktik secara berkelanjutan. Karena dampak pendemi covid-19 proses pembelajaran magang dilaksanakan secara daring, luring, dan melalui pendidikan informal dirumah. "Non-formal and informal learning, as well as voluntary activities, can also make an important contribution to the development of entrepreneurial skills, competences and mindsets" (Conclusions et al. 2014).

Program pendidikan kecakapan literasi komputer sebagai kegiatan yang memberikan bekal pengetahuan, keterampilan dan sikap kepada pemagang dalam proses mamasuki dunia usaha dan dunia industri yang semakin global. Struktur magang tradisional menggunakan 80\% praktik secara informal dari rumah dan untuk teori $20 \%$ dengan menggunakan daring, via WhatsApp Group. Sedangkan kontrak pembelajaran magang selama 3 bulan sejak bulan Februari sampai April 2020 dengan setiap minggu 2 kali pertemuan, dengan durasi 1,5 jam/ pertemuan. Untuk keseluruhan jam pelajaran (JP) magang adalah $36 \mathrm{JP}$, yang terbagi dalam 3 materi pengoprasian perangkat lunak terkait dengan pengolahan kata (word processing), pengolahan angka (exel processing) dan pengolahan presentasi (power point processing). Sedangkan materi untuk perangkat keras meliputi merakit, merawat, dan memperbaiki komputer sesuai dengan keselamatan dan kesehatan kerja (K3).

Bahan ajar magang yang digunakan dalam pelatihan literasi komputer merupakan bahan ajar yang sesuai dengan KKNI dan SKL Teknisi Komputer Jenjang III. Untuk keseluruhan pemagang merupakan peserta didik kesetaraan paket $\mathrm{C}$ untuk mempersiapkan UTBK. Karena dampak pendemi Covid-19 maka kegiatan pelatihan literasi komputer dilaksanakan secara daring dari masing-masing rumah pemagang (peserta didik). 
Penilaian magang dilakukan secara daring oleh tutor dan disesuaikan dengan capaian pembelajaran SKL. Selain itu juga penilaian dari orang tua, kerabat, saudara terdekat yang mengetahui tentang komputer. Untuk tindak lanjut magang menjadi kebijakan pengelola program dalam hal ini SKB. Tindak lanjut magang dilihat dari indikator peningkatan SDM, penguasaan keterampilan literasi komputer, dan penerapan keterampilan yang diperoleh selama magang.

Gambaran alur pendidikan kecakapan literasi komputer dengan konsep magang tradisional masa pendemi covid-19 dapat dilihat pada gambar 1 sebagai berikut:

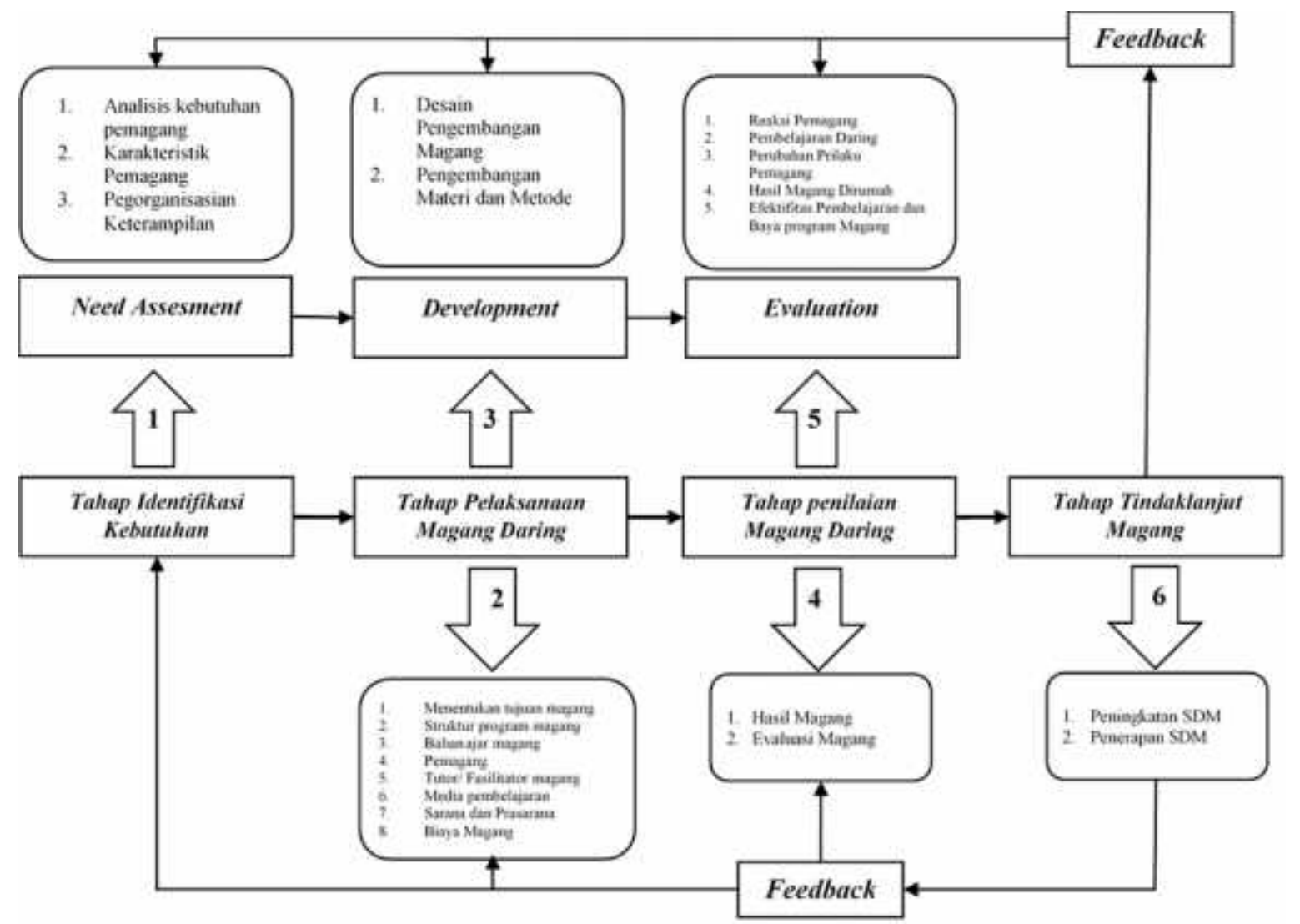

Gambar 1: Alur Program Pendidikan Kecakapan Literasi Komputer dengan Konsep Magang Tradisional Masa Pendemi Covid-19

\section{KESIMPULAN}

Literasi komputer di era pendemi covid-19 merupakan kebutuhan dasar manusia untuk menghadapi kenormalan baru. Mulai dari work from home, stay at home, dan learning at home. Dampak pendemi ini juga membatasi adanya kegiatan berkerumun, dengan physical distancing dan sosial distancing. Pengelolaan program pendidikan kecakapan literasi komputer masa pendemi Covid-19 di Sanggar Kegiatan Belajar (SKB) dengan kegiatan magang tradisional. Kegiatan pendidikan kecakapan literasi komputer mengacu pada standar kompetensi lulusan (SKL) dengan penguasaan sikap dan tata nilai, kemampuan bidang kerja, pengetahuan yang dikuasai, serta hak dan tanggung jawab pada bidang kerja. Sehingga pengelolaan program pendidikan kecakapan literasi dapat berjalan sesuai dengan tujuan program kecakapan literasi komputer.

Gambaran pola magang tradisional pendidikan kecakapan literasi komputer masa pendemi covid-19 menggunakan daring, luring dan offline. Pada proses belajar magang, pemagang 
belajar magang dari orang-orang terdekat, baik orang tua, saudara, dan kerabat. Secara umum magang tradisional dengan empat tahapan meliputi: 1) Tahap identifikasi kebutuhan peserta didik, meliputi keterampilan yang dipelajari dalam pendidikan literasi komputer, tujuan megang merakit, merawat dan memperbaiki komponen-komponen komputer. 2) Pelaksanaan magang, meliputi kegiatan pembelajaran secara daring, luring dan offline, praktik magang $80 \%$ dan teori $20 \%$ secara daring, Materi perangkat lunak tentang pengolahan kata (word processing), pengolahan angka (exel processing) dan pengolahan presentasi (power point processing), dan untuk pembelajaran perangkat keras meliputi perakitan, perawatan, dan perbaikan komponen-komponen yang sesuai dengan keselamatan dan kesehatan kerja (K3). 3) Mempelajari penilaian magang, meliputi penilaian secara daring oleh tutor, penilaian dari orang tua, saudara, kerabat terdekat yang memiliki kemampuan dalam bidang komputer.

\section{UCAPAN TERIMA KASIH}

Penulis mengucapkan terimakasih kepada Universitas Muhammadiyah Gresik yang telah memberikan kesempatan penulis dalam meneliti dan mengkaji secara mendalam tentang program pelatihan kecakapan literasi komputer melalui magang tradisional masa pendemi covid-19. Tak lupa penulis ucapkan terimakasih untuk mahasiswa PIAUD Universitas Muhammadiyah Gresik yang telah membantu penelitian ini.

\section{DAFTAR PUSTAKA}

Ariz, Denden. 2012. "Evaluasi Hasil Belajar Keterampilan Komputer Berbasis Kompetensi (Studi Kasus Kursus Komputer Program Aplikasi Dasar Di Lembaga Pendidikan Kursus Kharisma College Kecamatan Ciranjang Kabupaten Cianjur).” Jurnal EMPOWERMENT 1(2):2252-4738.

Budi Sudradjat. 2019. "Dampak Teknologi Dan Literasi Digital Terhadap Anak." Kompasiana. Retrieved (https://www.kompasiana.com/bsudradjat/5d765cfe097f3622a129f7f3/dampakteknologi-dan-literasi-digital-terhadap-anak?page=all).

Conclusions, Council, Recalling The, Political Background, T. O. This, A. S. Set, O. U. T. In, T. H. E. Annex, These Conclusions, I. N. Particular, T. H. E. European, Council S. Recent, Recommendation On, K. E. Y. Competences, F. O. R. Lifelong, and Stresses That. 2014. "Council Conclusions on Entrepreneurship in Education and Training." 32(December):1-6.

Creswell, John. 2015. Riset Pendidikan. kelima. Yogyakarta: Pustaka Pelajar.

Dindin, Jamaluddin. 2013. Paradigma Pendidikan Anak Dalam Islam. Bandung: CV Pustaka Setia.

Eti, Komalasari. 2019. "Peran Guru Dalam Media Dan Sumber Belajar Di Era Disrupsi." Prosiding Seminar Nasional Pendidikan FKIP Universitas Sultan Ageng Tirtayasa 2(1):439-48.

Kualifikasi, Kerangka, Nasional Indonesia, and Indonesian Qualification Framework. 2014. TEKNISI KOMPUTER JENJANG III Berbasis KKNI. Jakarta, Indonesia: Direktorat Pembinaan Kursus dan Pelatihan Direktorat Jenderal Pendidikan Anak Usia Dini, Nonformal dan Informal Kementerian Pendidikan dan Kebudayaan.

Lair, Daniel J. 2007. “'Survivor’ for Business People": A Critical-Rhetorical Engagement Of" The Apprentice" As Popular Management Discourse." ProQuest. 
Muliawaty, Lia. 2019. "Peluang Dan Tantangan Sumber Daya Manusia Di Era Disrupsi." Kebijakan : Jurnal Ilmu Administrasi 10(1):1.

Munir. 2017. Pembelajaran Digital. Bandung: Alfabeta.

Pembinaan, Direktorat, Kursus Dan, Direktorat Jenderal, Pendidikan Anak, and Usia Dini. 2014. "KOMPETENSI KURSUS DAN PELATIHAN KURIKULUM KURSUS VIDEO EDITING JARINGAN KOMPUTER DAN SISTEM Berbasis.”

Pers, Jurnal Dewan. 2017. “715-Buku Jurnal Dewan Pers 14 Indonesia.” (14).

Pratiwi, Nani, and Nola Pritanova. 2017. "Pengaruh Literasi Digital Terhadap Psikologis Anak Dan Remaja." Semantik 6(1):11.

Rezki, Annissa. 2020. "Kebijakan Pemberlakuan Lockdown Sebagai Antisipasi Penyebaran Corona Virus Covid-19.” SALAM; Jurnal Sosial \& Budaya Syar-I 7(3):227-38.

Rokhman. 2019. "Inilah 6 Literasi Dasar Yang Perlu Anda Tahu.” Kompasiana. Retrieved (https://www.kompasiana.com/omank/5a83a394dcad5b29f823ffe2/inilah-6-literasidasar-yang-perlu-anda-katahui?page=all).

Sandro, Galea and Raina M. Mercha. and Nicole Lurie. 2011. "The Mental Health Consequences OfCOVID-19 and Physical Distancing The Need for Prevention and Early Intervention Opinion.” Depression and Anxiety 28(8):666-75.

Sudjana, Djudju. 2004. Manajemen Program Pendidikan; Untuk Program Pendidikan Non Formal Dan Pengembangan Sumber Daya Manusia. Bandung: Falah Production.

Tim GLN Kemendikbud. 2017. "Materi Pendukung Literasi Digital." Kementerian Pendidikan Dan Kebudayaan 43. 